\title{
Implementasi budaya masyrakat Toraja
}

\author{
Mariana banne \\ e-mail marianabanne0303@gmail.com \\ Institut Agama Kristen Negeri Toraja
}

\begin{abstract}
ABSTRAK
Dalam jurnal ini akan memaparkan tentang budaya Toraja yang membentuk karakter masyrakatnya yang memiliki tujuan untuk menujukkan kepada kita bawa yang terpenting disini adanya karakter yang dimiliki orang setiap individu karena sering kali kita mengabaikan karakter karena adanya pendidikan yang tinggi kita miliki.Namun dengan adanya karaktr yang kita miliki dapat memberikan dampak positif pada diri kita dan orang lain.Adanya penelitian ini dapat memberikan gambaran kepada pembaca bahwa adanya kebijaksanaa yang dimiliki orang toraja yang dapat memberikan pemikiran yang berkualitas untuk munumbuhkan kualitas hidup sehimgga tidak menyalagunakan budaya
\end{abstract}

\begin{abstract}
In this journal, we will describe the Toraja culture that shapes the character of its people which has the aim of showing us that the most important thing here is the character that each individual has because we often ignore character because of our high education. have a positive impact on ourselves and others. The existence of this research can provide an illustration to the reader that there is wisdom possessed by the Toraja people who can provide quality thoughts to improve the quality of life so that they do not abuse culture.
\end{abstract}

\section{PENDAHULUAN}

Kebudayaan ini merupakan pertunjukkan dari keyakinan dan nilai nilai utam pada individu dengan adanya kebudayaan ini yang dipakai oleh setiap individu sebagai kostum 
dalam pertunjukkan dalam mengondisikan kebudayaannya dilingkungan sekitar .Dari Kebudayaan Toraja ini menggambarkan cara berfikirnya dan kuaitas hidupnya sehingga dngan adanya kebudayaan orang toraja tersebut dapat dilakukan dengan sebaik mungkin agar dapat mencerminkan karakter yang baik .nmun yang terpenting disini ialah tidak menyepelekan kebudayaan itu dalam melakukan kebudayaan tersebut juga dapat mencerminkan iman mereka dimana kita ketahui bah wa adanya upacara misalya rambu tuka danrambu solo yang dirangkaikan dengan ibadah yang menandakan adanya pengharapan kepada Tuhan agar ${ }^{123}$ dituntun dalam upacara tersebut . Kebudayaan ini memiliki suatu keyakinan perekat yaitu pandangan terhadap kehidupan dan realita yang dapat melestarikan kesatuan ,keyakinan seperti kepercayaan pada budaya yang berbeda dari dasar kristen namun kebudayaan pada umumnya mengalami kesulitan dalam mempercayai ordo dunia yang seharusnya menjadi teladan bagi dunia. Namun yang terpenting disini kita lebih mempercayai nilai nilai dan kepercayaan kita yang tertinggi itu benar.

Dalam kebuayaan ini perluh kita ketahui perkembangan suatu pandangan yang benar untuk bertindak adil dan bijaksana dalam menyikapi perkembangan zaman ahar nilai nilai dalam kebudayaaan Toraja tidak hilang sehingga kita perluh untuk bertindak bijaksana sebagai penerus bangsa dan negara namun bukan berarti kita tertutup dalam hal ini namun perluhnya untuk mengikuti perkembangan zaman dengan terbuka tanpa menghilangkan nilai nilai kebudayaan dengan tetap berkarya agar dapat memberikan manfaat bagi pelaku budaya dan yang memilki antusias untuk menjunjung pendidikan .Dalam pendidikan penanaman nilai dan pembentukan karakter karena adanya pendidikan memberikan tempat pada realita untuk lebih memajukan kebudayaan yang ada namun dengan adanya budaya modern .Dalam mengetahui ilmu tersebut adanya usaha untuk mempelajari dengan adanya niat untuk mengetahui sesuatu namun bukan dengan adanya ilmu yang kita miliki membuat kita untuk melupakan kebudayaan namun dengan adanya ilmu tersebut kita dapat mengembangkan kebudayaan dengan adanya proses yang berlangsung. Adanya perbedaan budaya yang kita miliki seperti pada diri masing

\footnotetext{
${ }^{1}$ Rannu sanderan “ jurnal ilmiah religiosity entity humanity “

${ }^{2}$ Rannu sanderan "exemplary menemukan kunci pendidikan iman bagi anak dalam keluarga dan pembelajaran agama di sekolah"

${ }^{3}$ Rannu sanderan " disiplin karisma dan harmoni kontribusi disiplin diri bagi pengembangan pendidikan Kristen"
} 
masing yang memiliki karakter yang berbeda namun bagaimana cara kita untuk mengembangkan karakter yang baik pada setiap individu.Dengan adanya akal yang di miliki oleh manusia sehingga mampu untuk berbudaya melalui firman Allah dengan mampu mengembangkan budaya termasuk dalam berkomunikasi dengan adanya perubahan peradaban sehingga dengan adanya perkembangan budaya kemajuan telah membawa manusia pada bukti keistimewaan sebagai ciptaan Allah. Adanya sebuah pendidikan kristen dapat membawa kita untuk berjalan menuju keselamatan .secara teologis pendidikan agama memberikan tanggung jawab yang mencakup sisi positif maupun negatif dari segala komunitas atau tradisi yang ada dari hal tersebut muncul adanya pelayanan dalam pendidikan yang dihadapi oleh setiap individu .

\section{TUJUAN DAN MANFAAT}

Tujuan dalam penulisan makalah ini agar pembaca dapat memahami kebudayaan toraja dan memahami bahwa kebudayaan itu mencerminkan karakter setiap individu sehingga tidak mengabaikan kebudayaan irtu tetapi memperlenalkan dan terus mengembangkan dengan adanya ilmu pendidikan yang dimiliki dengan tetap berfikir bijaksana dalam menata masa depan unrtuk menjadi penerus dalam mengimplementasikan maksud dan tujuan kebudayaan ini .Adapun manfaat dalam penulisan makalah ini dapat memberikan pemahaman kepada pembaca bahwa adanya keberagaman budaya dalam suatau bangsa maka perluhnya bagi setiap individu untuk memperkaya kebudayaan itu dengan tetap mengembangkanya .

\section{PEMBAHASAN}

Kita harus bertindak dengan bijaksana baik dalam menyikapi kebudayaan maupun dalam setiap kegiatan yang kita lakukan dalam kehidupan sehari hari dengan adanya keterbukaan tentang adat dan kebudayaan kita dengan memberikan manfaat kepada orang disekitar kita ataupun orang yang tidak mengenal kebudayaan tersebut namun dengan adanya ilmu yang kita miliki untuk mengembangkan kebudayaan kita sebagai suatu cerminan atau tindakan yang baik dalam mendukung adanya kebudayaan .Dalam hal ini agama bertanggung jawab sepenuhnya tentang sisi positif maupun negatif dari segala interaksi atau apa yang kita lakukan dengan komunitas atau tyradisi dengan adanya pelayan didalamnya melalui pemberitaan firmaan dan 
kegiatan yang sesuai dengan firman Allah .Dalam melakukan upacara kebudayaan kita dahulukan dengan adanya ibadah sebagai tanda bahwa kita menyerahkan semuanya kepaa Tuhan apa yang kita lakukan dalam al ini kita mengembangkan nilai nilai dan kebenaran firman Tuhan melalui ibadah tersebut .Oleh karena itu kita dapat menuju perubahan melalui tindakan yang kita lakukan .Para guru guru agama da pat memberikan pengajaran lansung dalam komunitas atau kebudayaan dengan turut berinteraksi untuk menggali ilmu dalam kebudayaan agar kebudayaan tersebut memiliki tinjauan yang baik dalam masyrkat. ${ }^{4}$ Dengan adanya pendidikan dalam agama ini dapat memberikan pemahaman kepada semua masrkat untuk melakukan apa yang dikehendaki Allah termasuk dalam kebudayaan dusetiap daerah untuk menjalankan kebudayaan yang ada tanpa menyesampingkan kepercayaan kepada Tuhan .Namun dengan adanya perkembangan tersebut karena adanya pendidikan dapat memberikan dampak yang lebih baik dalam kehidupan masyrkat dengan memiliki tindakan yang sesuai difirmankan Alkitab dengan tetap berkarya dan memberikan manfaat keoada orang lain sehingga mampu menarik mereka untuk bertindak sebagaimana mestinya. Budaya modernisme membawa berbagai perubahan dan kemudahan bagi umat manusia baik dilingkungan kita maupun di daerah yang tidak kita jangkau pasti banyak perubahan yang terjadi karena adanya teknologi namun dengan adanya perubahan ini bukan berarti kita tidak lagi mempedulikan keebudayaan kita tetapi dengan kemajuan teknologi kuta lebih waspada untuk tidak mengikuti kemajuan tersebut dengan hal hal yang tidak nsesuai apa yang difirmankan oleh Tuhan namun marilah kita menumbuhkan karakter yang lebih bermanfaat ,bukan berartyi adanya kemajuan teknologi yang memberikan kemudahan membuat kita untuk memberikan kesengsaraan dengan mencari kepuasan diri kita sendiri namun marilah kita kembangkan kebudayaan itu disiplin asketisme

Ketika manusia memasuki dunia sebagai keberadaan yang realitas maka akan mewujudkan peran mereka didunia ini dengan mengikuti agama ,budaya, dan sosial sebab hal itu ada dalam alam ini sehingga, tentang masalah ini Tuhan mengandalkan kita untuk membawa gambarnya seperti yang kita tahu bahwa ia berkata berbuahlah penuhilah bumi dan kuasailah ikan ikan dan burung burung dan semua binatang baik yang di darat maupun yang di laut

\footnotetext{
${ }^{4}$ Rannu sanderan " acceptance after reviewing this thesis, with the title, tosangserekan A Theological Reflection on the Integrity of Creation in the Torajaan Context"
} 
sehingga kita ketahui bahwa kita memiliki hak penuh untuk menjaga dan melestarikan alam sebab ia sendiri yang memberikan kita amanat untuk menjaga alam ini . .Kita perluh untuk melakukan hl hal yang tlah dilakukan yesus dengan tidak sombong tetapi tetap merendahkan diri dengan menampilkan kesederhanaan dalam hidup kita namun kembali ditegaskan bahwa bukan dengan adanya ilmu yang kita miliki menjadikan kita untuk menjadi manusia yang angkuh dan sombong karena kita tahu Allah mengajarkan kesederhanaan .Sering sekali dalam kehiduopan kita dengan memiliki ilmu dan harta yang banyak sehingga apa yang diajarkan Tuhan kepada kita bertolak belakang dengan yang kita lakukan namun marilah kita kembali kepada firman Allah untuk tetap menjadi pribadi yang sederhana

accepetance

\section{KESIMPULAN}

Materi kebudayaan yang telah di paparkan diatas memberikan pemahaman kepada setiap pembaca bahwa kita harus memiliki karakter yang baik yang mencerminkan bahwa kita menerapkan kebudayaan itu karena dengan berpendidikan yang tinggi tetapi tidak memiliki karakter tidaklah cukuptetapi marilah kita untuk tetap berfikir bijak dalam menerapkan budaya tersebut.

\section{SARAN}

Kebudayaan adalah identitas kita dimana pun brada maka marilah kembangkan budaya itu dengan berpartisipasi dalam melakukan kebudayaan tersebut ,kebudayaan kita adalah cerminn tingkah laku kita maka tetaplah bijak dalam mengembangkan kebudayaan tersebut dengan menerapkan hal hal yang positif dan terlebih tetap rendah hati seperti yang Yesus ajarkan kepada kita . 
